\title{
SANITARY-AND-EPIDEMIOLOGICAL SUBSTANTIATION OF THE CONDITIONS FORTHELOCATION OF MODERN LOW-CAPACITY ENIERPRISES FOR MANUFACTURE OF ASPHALI CONCREIE TAKING INTO ACCOUNT CHANGES IN TECHNOLOGY
}

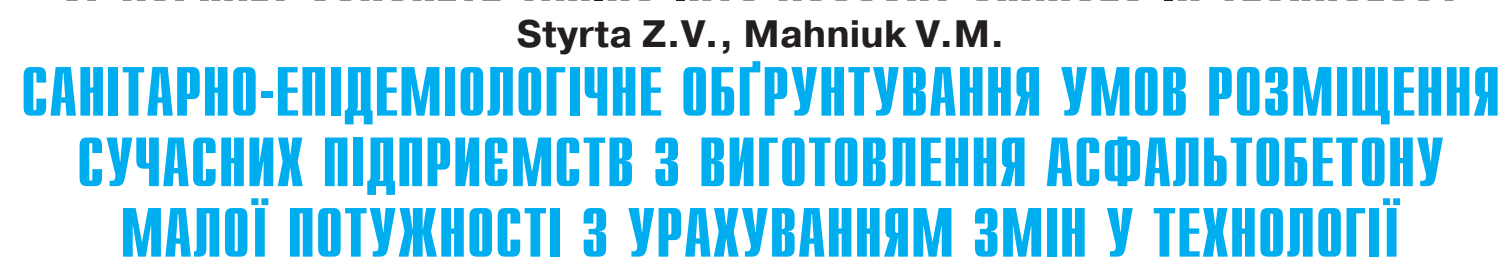

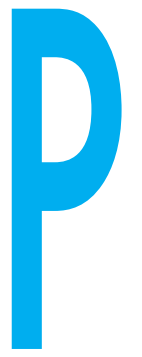

СТИРТА 3.В.

МАХНЮК В.М.

ДУ «Інститут

громадського здоров'я

ім. О.М. Марзєєва

НАМН України», м. Київ еалізація євроінтеграційних планів України поступово сприяє наближенню показників вітчизняного транспортного сектору до європейських - насамперед у контексті збільшення обсягів вантажів, перевезених автомобільним транспортом, дальності перевезень та кількості автотранспортних засобів у використанні. Протягом останніх років (2015-2019) зросла частка автомобільного транспорту у загальному обсязі вантажних перевезень, що свідчить про переорієнтацію вантажопотоків на цей вид транспорту. Нині в Україні у багатьох випадках автомобільний транспортний сектор виступає у ролі лімітуючого фактора, що стримує розвиток економіки, зменшує її конкурентоспроможність. Неконтрольоване навантаження на українські дороги при автоперевезеннях призвело до технічного їх виснаження. За оцінкою Всесвітнього Економічного Форуму, Україна за якістю автомобільних доріг посідає 130 місце із 137 і вже тривалий час поступається не лише країнам Західної Європи, але і країнам Східної Європи (країнам колишнього CPCP) [1].

В умовах децентралізації, яка на сьогодні $€$ внутрішнім курсом нашої держави й покликана забезпечити якісні і доступні послуги людям незалежно від місця прожи-
САНІТАРНО-ЕПІДЕМІОЛОГІЧНЕ

ОБГРУНТУВАННЯ УМОВ РОЗМІЩЕННЯ

СУЧАСНИХ ПІДПРИЕМСТВ МАЛОЇ

ПОТУЖНОСТІ З ВИГОТОВЛЕННЯ

АСФАЛЬТОБЕТОНУ З УРАХУВАННЯМ ЗМІН

У ТЕХНОЛОГІЇ

Стирта 3.В., Махнюк В.М.

ДУ «Інститут громадського здоров'я

ім. О.М. Марзєєва НАМН України»,

м. Київ, Україна

Мета роботи. Санітарно-епідеміологічне та еколого-гігієнічне обґрунтування умов розміщення асфальтобетонних заводів (АБЗ) малої потужності, розробка гігієнічних критеріїв до їх розташування з урахуванням новітнього вітчизняного санітарного, екологічного та містобудівного законодавств та вимог директив Європейського Союзу. Матеріали та методи досліджень. У статті використано бібліосемантичні, аналітичні методи та результати санітарно-епідеміологічної експертизи проектних матеріалів. Результати досліджень. Проаналізовано санітарне законодавство України 1971 та 1996 років у частині унормування санітарно-захисної зони (СЗ3) для АБЗ та порівняння з аналогічними нормативами європейських країн. За результатами наукової санітарно-епідеміологічної експертизи проектних матеріалів щодо обгрунтування СЗЗ для вітчизняних АБЗ малої потужності (80\% з яких вве- дено в експлуатацію до 1996 року) встановлено наступне. Усі досліджені підприємства працюють на готовому бітумі з впровадженням природоохоронних заходів шляхом використання високоефективних пилогазоочисних систем, що значною мірою скоротило валові викиди забруднюючих речовин в атмосферне повітря та зменшило вплив на довкілля та прилеглу сельбищну територію, що відповідає вимогам Директиви 2010/75/ЄС Європейського Парламенту та Ради з промислових викидів (інтегроване запобігання та контроль забруднення) від 24 листопада 2010 року.

Впровадження природоохоронних заходів з використанням високоефективних пилогазоочисних систем на існуючих АБЗ малої потужності забезпечило відсутність перевищень ГДК специфічних забруднюючих речовин на відстанях, які були меншими за нормативну СЗ3 в 1,5-3,0 рази, що дало підстави для обґрунтування використання нового підходу до встановлення СЗЗ - за розрахунковим методом під час будівництва нових чи реконструкції існуючих АБЗ малої потужності.

Ключові слова: асфальтобетонні заводи малої потужності, забруднюючі речовини, герметизація технологічних процесів, природоохоронні заходи, санітарно-захисні зони, пооб'єктний розрахунковий метод.

( Стирта 3.В., Махнюк В.М. СТАТТЯ, 2020. 
SANITARY-AND-EPIDEMIOLOGICAL SUBSTANTIATION OF THE CONDITIONS FORTHELOCATION OF MODERN LOWCAPACITY ENTERPRISES FOR MANUFACTURE OF ASPHALT CONCRETE TAKING INTO ACCOUNT CHANGES IN TECHNOLOGY Styrta Z.V., Mahniuk V.M.

SI «Marzieiev O.M. Institute for Public Health, National Academy of Medical Sciences of Ukraine», Kyiv, Ukraine

Objective: We performed sanitary-and-epidemiological and ecological-and-hygienic substantiation of the conditions for the location of lowcapacity enterprises for the manufacture of asphalt concrete, developed the hygienic criteria for their location taking into account the newest home sanitary, ecological and town-planning legislations and requirements of the European Union directives.

Materials and methods: In the article we used results of sanitary-and-epidemiological examination of the project materials and applied bibliosemantic, analytical methods.

Results: The sanitary legislation of Ukraine of 1971 and 1996 in the normalization of sanitaryand-protection zone for the above mentioned enterprises was analyzed and compared with the analogous standards in the European countries. According to the results of the scientific sanitaryand-epidemiological examination of the project materials on the substantiation of the sanitaryand-protection zone for home low-capacity enterprises for the manufacture of asphalt con- crete $(80 \%$ of them were put into operation before 1996), the following was established. All investigated enterprises work with the prepared bitumen with the implementation of nature protection measures by means of the use of high-efficiency dust and gas cleaning systems, that shortened the gross emissions of the pollutants in ambient air to a large extent and decreased influence on the environment and adjoining settlement territory, that complies with the requirements of the Directive of 2010/75/EC of European Parliament and Council on the industrial emissions (integrated prevention and control of contamination), November 24, 2010. Implementation of nature protection measures with the use of the high-efficiency dust and gas cleaning systems at the existent low-capacity enterprises for the manufacture of asphalt concrete provided the absence of the exceed of MPC of the specific pollutants at the distances that were 1.5-3.0 times less than standard sanitary-protective zone that was a cause for the substantiation of the use of new approach at the establishment of sanitary-and-protection zone by the calculation method at building of the new or reconstruction of the existent low-capacity enterprises for the manufacture of asphalt concrete.

\section{Keywords: low-capacity asphalt concrete plants, pollutants, sealing of technological processes, nature protection measures, sanitary-and-protection zones, object-by-object calculation method.}

вання, набуває важливого значення досягнення належної якості комунальних доріг.

у зв'язку з розбудовою на території України міждержавних автомобільних коридорів, автомагістралей державного, регіонального та місцевого значення в останнє десятиліття все більше активізується розвиток дорожньої галузі, який спонукає до збільшення виробництва будівельних матеріалів, у тому числі асфальтобетону [2].

Оскільки в Україні частка асфальтобетонного покриття становить майже 98\% серед усіх інших видів покриттів, виробництво асфальтобетону має тенденцію до нарощування потужностей та впровадження інноваційних технологій, що відповідає вимогам європейських стандартів. Для забезпечення виробництва великих обсягів дорожньобудівельних матеріалів у країні у 80\% випадків відновлюється робота асфальтобетонних заводів (АБЗ) територіальних шляхово-ремонтних управлінь, які функціонували до 1996 року та мали малу проектну потужність [3].

Актуальність дослідження зумовлена відсутністю у національному санітарному законодавстві санітарно-гігієнічних вимог до розміщення АБЗ, у тому числі малої потужності, з урахуванням впровадження природозахисних заходів.

Метою даного дослідження $€$ санітарно-епідеміологічне та еколого-гігієнічне обґрунтування умов розміщення АБЗ малої потужності, розробка гігієнічних критеріїв до їх розташування 3 урахуванням новітнього вітчизняного санітарного, екологічного та містобудівного законодавств та вимог директив Європейського Союзу.

Предмет дослідження: нормативна база санітарного, екологічного та містобудівного законодавств, проектні матеріали щодо розташування асфальтобетонних заводів малої потужності, показники забруднення атмосферного повітря.
Методи дослідження. Дослідження базувалися на аналізі чинних національних санітарного, екологічного і містобудівного законодавств у сфері розташування та організації промислових зон та відповідності їх міжнародним вимогам.

Використовували бібліосемантичні (для аналізу використання нормативно-правового регулювання, наукової літератури у сфері містобудування), теоретичні (ретроспективне використання даних наукових досліджень), експертно-аналітичні (для гігієнічної оцінки проектних рішень, розрахункових приземних концентрацій забруднюючих речовин в атмосферному повітрі, акустичних розрахунків та результатів натурних досліджень) методи дослідження та санітарно-епідеміологічної експертизи проектних матеріалів щодо обґрунтування встановлення санітарно-захисних зон для підприємств з виробництва асфальтобетону. 
Результати та їх обговорення. У ході досліджень у 2018-2019 роках співробітниками лабораторії гігієни планування та забудови населених місць ДУ «ІГЗ НАМН України» було проведено наукову санітарно-епідеміологічну оцінку проектів розміщення та функціонування 20 підприємств 3 виготовлення асфальтобетону малої потужності на відповідність вимогам санітарного, екологічного та містобудівного законодавств. Нині базовим нормативним документом у сфері планування та забудови населених місць $€$ «Державні санітарні правила планування та забудови населених пунктів. ДСП № 173-96», затверджені наказом МОЗ України № 173 від 19.06.1996, зареєстрованим у Міністерстві юстиції України 24.07.1996 за № 379/ 1404, та «Санітарна класифікація підприємств, виробництв та споруд і розмірів санітарно-захисних зон для них», яка викладена у Додатку № 4 цього документа, за яким для «Виробництва асфальтобетону» встановлено санітарно-захисну зону (СЗ3) розміром 1000 м [4].

За результатами проведених досліджень встановлено, що із 20 досліджуваних АБЗ 80\% підприємств були збудовані до 1996 року (2 заводи 1956-1960 рр., 12 заводів 1960-1985 рр., 2 заводи 1986-1992 рр.). Для зазначених підприємств на момент введення їх в експлуатацію була чинною нормативна СЗ3 розміром у 300 м відповідно до вимог діючих на той час «Санитарных норм проектирования промышленных предприятий. СН 245-71». За цей період на зазначених об'єктах неодноразово здійснювалася модернізація технологічного обладнання 3 впровадженням герметизації, автоматизації технологічних процесів, застосуванням ефективного пилогазоочисного обладнання для зменшення викидів забруднюючих речовин в атмосферу. Окрім того, у технологічному процесі виробництва асфальтобетону передбачено до застосування готовий привозний бітум на виконання наказу Держслужби автошляхів України

Таблиця

Валові викиди забруднюючих речовин від підприємств малої потужності

\begin{tabular}{|c|c|c|c|}
\hline $\begin{array}{c}\text { Назва об'єкта, тип } \\
\text { АЗу }\end{array}$ & \begin{tabular}{|c|} 
Потужність \\
т/рік, \\
запроекто- \\
ваний \\
розмір СЗ3
\end{tabular} & $\begin{array}{l}\text { Валові викиди, } \\
\text { т/рік }\end{array}$ & $\begin{array}{c}\text { Природоохоронні } \\
\text { заходи }\end{array}$ \\
\hline $\begin{array}{l}\text { № 1. АБЗ філії } \\
\text { «Кремінський } \\
\text { райавтодор», } \\
\text { Луганська } \\
\text { область, } \\
\text { Кремінський } \\
\text { район, } \\
\text { М. Кремінна, } \\
\text { АЗУ - ДС-158 }\end{array}$ & $\begin{array}{c}14,993 \text { тис. } \\
920 \mathrm{~m} \\
\text { у Пд-3x } \\
910 \text { м у } \\
\text { Зх } \\
\text { напрямках }\end{array}$ & $\begin{array}{c}\text { 19,56, у т.ч. діоксид азоту - 1,1414, діоксид сірки - } \\
\text { 4,2916, бензол - 6,0Е-7, фенол - 0,000211, } \\
\text { пентан - 0,1950, оксид вуглецю - 6,8836, оксид } \\
\text { заліза - 0,0011, марганець і його сполуки - 0,0002, } \\
\text { речовини у вигляді суспендованих твердих } \\
\text { частинок, не диференційованих за складом - } \\
\text { 7,0, бенз(а)пірен - 3,2Е-12, сірководень - 9,0Е-4 }\end{array}$ & $\begin{array}{c}\text { Триступенева система } \\
\text { пило-газоочистки (осьовий } \\
\text { прямоточний циклон з ефек- } \\
\text { тивністю роботи } 41,1 \% \text {, група } \\
\text { з чотирьох циклонів СЦН-40 з } \\
\text { ефективністю роботи } 92,9 \% \\
\text { та мокрий пиловловлювач } \\
\text { ударно-інерційної дії } 3 \\
\text { ефективністю очистки } 78,9 \%)\end{array}$ \\
\hline $\begin{array}{l}\text { № } 2 \text { АБЗ філії } \\
\text { «Старобільська } \\
\text { ДЕД» Луганська } \\
\text { Область, } \\
\text { Старобільський } \\
\text { район, } \\
\text { с. Половинкине, } \\
\text { АЗУ - } \\
\text { «TeltomatV/3-S» }\end{array}$ & $\begin{array}{c}19,99 \text { тис. т } \\
700 \text { м у } 3 x \\
\text { та } 650 \text { м } \\
\text { у Пд-3x } \\
\text { напрямках }\end{array}$ & \begin{tabular}{|c|}
24,45, у т.ч. діоксид азоту - 2,0059, діоксид \\
сірки - 4,8156, бензол - 2,8Е-4, фенол - 0,000263, \\
вуглеводні ароматичні - 1,002Е-5, суміш \\
вуглеводнів насичених - 0,3357, оксид вуглецю - \\
12,7136, оксид заліза - 0,0016, марганець \\
і його сполуки - 0,0002, речовини у вигляді \\
суспендованих твердих частинок, \\
не диференційованих за складом - 4,5776, \\
бенз(а)пірен - 3,2Е-11, сірководень - 0,00123.
\end{tabular} & $\begin{array}{c}\text { Двоступенева система } \\
\text { пило-газоочистки } \\
\text { (пилоосаджувальна камера } \\
\text { з ефективністю очистки 42,5\% } \\
\text { та група з чотирьох циклонів } \\
\text { СК-ЦН-33-800 з ефективністю } \\
\text { очистки 98,7\%) }\end{array}$ \\
\hline $\begin{array}{l}\text { № } 3 \text { АБЗ ТОВ } \\
\text { «МЕГО ЛТД» } \\
\text { Закарпатська } \\
\text { область, } \\
\text { Тячівський район, } \\
\text { Смт. Буштино, АЗУ } \\
\text { - КДМ-20137 }\end{array}$ & $\begin{array}{c}30 \text { тис. т } \\
480 \mathrm{~m} \\
\text { у Пд-3x } \\
480 \mathrm{M} \\
\text { у Пд, } 890 \mathrm{~m} \\
\text { у Пд-Сх } \\
\text { напрямках }\end{array}$ & \begin{tabular}{|c|} 
26,64, у т.ч. діоксид азоту - 8,85, оксид вуглецю - \\
6,595, діоксид сірки - 0,81, ксилол - 0,024, \\
фенол - 0,00055, етилен - 0,15, речовини у вигляді \\
суспендованих твердих частинок, не диференційо- \\
ваних за складом - 0,0194, пил неорганічний, який \\
містить двоокис кремнію 70-20\% - 9,02, суміш \\
вуглеводнів насичених С12-C19-0,651, \\
бенз(а)пірен - 3,2Е-10, оксид ванадію (V) - 1,1Е-5. \\
\end{tabular} & \begin{tabular}{|c|} 
\\
Двоступенева система \\
пило-газоочистки (циклон \\
прямоточний та група з шести \\
циклонів СЦН-40, скрубер \\
«Вентурі») з ефективністю \\
очистки 99,9\% \\
\end{tabular} \\
\hline $\begin{array}{l}\text { № } 4 \text { АБЗ ПрАТ } \\
\text { «Ковельське } \\
\text { ШБУ-63», } \\
\text { Волинська } \\
\text { область, } \\
\text { м. Ковель, } \\
\text { АЗУ - ДС-1683 }\end{array}$ & $\begin{array}{l}39,36 \text { тис. т } \\
844 \text { м у } \\
\text { Пн-Сх, } 785 \text { м } \\
\text { у Сх, } 724 \text { м } \\
\text { у Пд-3x, } \\
567 \text { м у } 3 x \\
\text { напрямках }\end{array}$ & \begin{tabular}{|c|} 
20,24, у т.ч. діоксид азоту - 1,373, діоксид сірки - \\
1,107, бензол - 8,2Е-8, фенол - 7,1Е-6, вуглеводні \\
насичені - 1,205, оксид вуглецю - 3,95, сажа - \\
0,177, ванадій та його сполуки - 0,0845, речовини у \\
вигляді суспендованих твердих частинок, \\
не диференційованих за складом - 12,343, \\
сірководень - 1,54Е-7, бенз(а)пірен - 7,7Е-6
\end{tabular} & \begin{tabular}{|c|} 
Триступенева система пило- \\
газоочистки (прямоточний \\
циклон з ефективністю роботи \\
38\%, група з восьми циклонів \\
СЦН-40 з ефективністю робо- \\
ти 95\% та мокрий пиловлов- \\
лювач ударно-інерційної дії \\
з ефективністю очистки 96\%)
\end{tabular} \\
\hline $\begin{array}{l}\text { № } 5 \text { АБЗ ТОВ } \\
\text { «ДРБУД», } \\
\text { Запорізька } \\
\text { область, } \\
\text { Якимівський } \\
\text { район, } \\
\text { смт. Якимівка, } \\
\text { АЗУ - ДС-185 }\end{array}$ & $\begin{array}{l}50,0 \text { тис. т } \\
300 \mathrm{~m} \\
\text { у Пн-3x, } \\
315 \mathrm{~m} \\
\text { у } 3 \mathrm{x}, 392 \mathrm{~m} \\
\text { Пд-3x, 483 м } \\
\text { у Пн, } 575 \mathrm{~m} \\
\text { у ПН-Сx } \\
\text { напрямках }\end{array}$ & \begin{tabular}{|c|} 
21,49, у т.ч. діоксид азоту - 1,8388, діоксид сірки - \\
4,1461, ксилол - 0,002, фенол - 0,002, етилен - \\
0,002, вуглеводні ароматичні - 2,4Е-06, оксид \\
вуглецю - 9,84, оксид заліза - 5,4Е-6, марганець і \\
його сполуки - 6,0Е-5, свинець і його сполуки - \\
6,2Е-7, речовини у вигляді суспендованих твердих \\
частинок, не диференційованих за складом - \\
1,01842, суміш насичених вуглеводнів - 3,9666, \\
бенз(а)пірен - 5,0Е-05, сірководень - 5,1Е-6
\end{tabular} & $\begin{array}{c}\text { Триступенева система } \\
\text { пило-газоочистки (циклон пря- } \\
\text { моточний осьовий, група з } \\
\text { чотирьох циклонів СЦН-40, } \\
\text { скрубер «Вентурі») } \\
\text { з ефективністю очистки 99\% }\end{array}$ \\
\hline
\end{tabular}


САНИТАРНО-ЭПИДЕМИОЛОГИЧЕСКОЕ ОБОСНОВАНИЕ УСЛОВИЙ РАЗМЕЩЕНИЯ СОВРЕМЕННЫХ ПРЕДПРИЯТИЙ МАЛОЙ МОЩНОСТИ ПО ИЗГОТОВЛЕНИЮ АСФАЛЬТОБЕТОНА С УЧЕТОМ ИЗМЕНЕНИЙ В ТЕХНОЛОГИИ

Стырта 3.В., Махнюк В.М.

ДУ «Институт общественного здоровья им. А.Н. Марзєєва НАМН Украины», г. Киев, Украина

Цель работы. Санитарно-эпидемиологическое и эколого-гигиеническое обоснование условий размещения АБЗ малой мощности, разработка гигиенических критериев к их размещению с учетом новейшего отечественного санитарного, экологического и градостроительного законодательства и требований директив Европейского Союза.

Материалы и методы исследований. $B$ статье использованы библиосемантический, аналитический методы и результаты санитарно-эпидемиологической экспертизы проектных материалов.

\section{Результаты исследований.}

Проанализировано санитарное законодательство Украины 1971 и 1996 годов в части нормирования СЗЗ для АБЗ по сравнению с аналогичными нормативами европейских стран. По результатам научной санитарноэпидемиологической экспертизы проектных материалов по обоснованию СЗЗ для отечественных АБЗ малой мощности (80\% из которых введено в эксплуатацию до 1996 года) установлено следующее. Все исследуемые предприятия работают на готовом битуме с внедрением природоохранных мероприятий путем использования высокоэффективных пыле-газоочистительных систем, что в значительной степени сократило валовые выбросы загрязняющих веществ

в атмосферный воздух и уменьшило влияние на окружающую среду и прилегающую селитебную территорию, что отвечает требованиям Директивы 2010/75/EC Европейского Парламента и Совета по промышленным выбросам (интегрированное предотвращение и контроль загрязнения) от 24 ноября 2010 года.

Внедрение природоохранных мероприятий с использованием высокоэффективных пылегазоочистительных систем на существующих АБЗ малой мощности обеспечило отсутствие превышений ПДК специфических загрязняющих веществ на расстояниях, которые были меньше нормативной СЗ3 в 1,5-3,0 раза, что дало основание для обоснования использования нового подхода при установлении СЗЗ по расчетному методу при строительстве новых или реконструкции существующих АБЗ малой мощности.

\section{Ключевые слова: асфальтобетонные заводы малой мощности, загрязняющие вещества, герметизация технологических процессов, природоохранные мероприя- тия, санитарно-защитные зоны, пообъектный расчетный метод.}

про заборону використання чорнов'яжучих матеріалів коксохімічного виробництва (дьогтю, смоли тощо) від 27.10.2005 № 490 .

Слід зазначити, що на сьогодні основна кількість АБЗ працює на базі мобільних модифікацій асфальтозмішувальних установок (АЗУ), що дає змогу розміщувати їх у безпосередній близькості від об'єктів будівництва (автострад) з віддаленням від сельбищної території. Разом з тим, виробництво асфальтобетону має сезонний характер, що зменшує вплив на стан навколишнього середовища у часі.

Слід зазначити, що для розміщення досліджуваних АБЗ виділялися земельні ділянки, які наближені до доріг та віддалені від населених пунктів на відстань від 500 м до 1000 м.

Населені пункти, на території яких розміщувалися АБЗ, з часом розбудовувалися, наближаючи житлову забудову до вже існуючих підприємств. Після введення у дію нового українського нормативного документа ДСП 173-96 (1996) для виробництва асфальтобетону було внормовано новий розмір С33 у 1000 м, якого нині не завжди дотримуються досліджені АБЗ.

Сучасне обладнання 3 виробництва асфальтобетону, яке впроваджено на досліджених АБЗ, відповідає вимогам європейських стандартів у частині використання новітніх технологічних інновацій та слугує зменшенню валових викидів забруднюючих речовин, що відповідає основним вимогам Директиви 2010/75/ЄС Європейського Парламенту та Ради з промислових викидів (інтегроване запобігання та контроль забруднення) від 24 листопада 2010 року [5].

Одним 3 ключових елементів Директиви 2010/75/€C є впровадження на промислових об'єктах найкращих доступних технологій та методів керування.

Найкращі доступні технології та методи керування (НДТМ) (з англ. Best available tech- niques - BAT) - це найбільш ефективні з точки зору захисту довкілля технології, розроблені з урахуванням особливостей промислових секторів та економічної доцільності їх впровадження. Також це такі способи експлуатації промислового об'єкта, за умови використання яких забезпечується запобігання або, де це не $є$ здійсненним, зменшення обсягів промислового забруднення та негативного впливу на навколишнє природне середовище.

Очікуваним результатом впровадження промисловим об'єктом НДТМ є досягнення низьких обсягів забруднення: викидів забруднюючих речовин в атмосферне повітря, скидів зворотних вод у водні об'єкти та стічних вод підприємств у системи каналізації, забруднення ґрунтів або підземних вод як наслідок операцій поводження 3 відходами тощо [5].

На досліджених АБЗ основними забруднюючими речовинами, що виділяються в

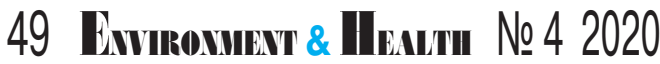


атмосферне повітря у процесі приготування асфальтобетонної суміші, $є$ неорганічний пил, продукти згорання палива (діоксид азоту, оксид вуглецю, бенз(а)пірен), продукти випаровування нафтопродуктів (бензол, ксилол, толуол, етиленбензол, фенол, ацетальдегід, формальдегід, ацетон, насичені вуглеводні) $[3,6]$.

Валові річні викиди забруднюючих речовин від підприємств малої потужності надано у таблиці.

За потужністю досліджені АБЗ розподілено таким чином: два АБЗ мають потужність до 20 тис. т/рік (14,993 тис. т та

\section{Загальний обсяг річних валових викидів (т/рік) залежно від потужності підприємств (тис. т/рік) та ефективності пило-газоочисних систем (II - двоступенева, III - триступенева системи)}

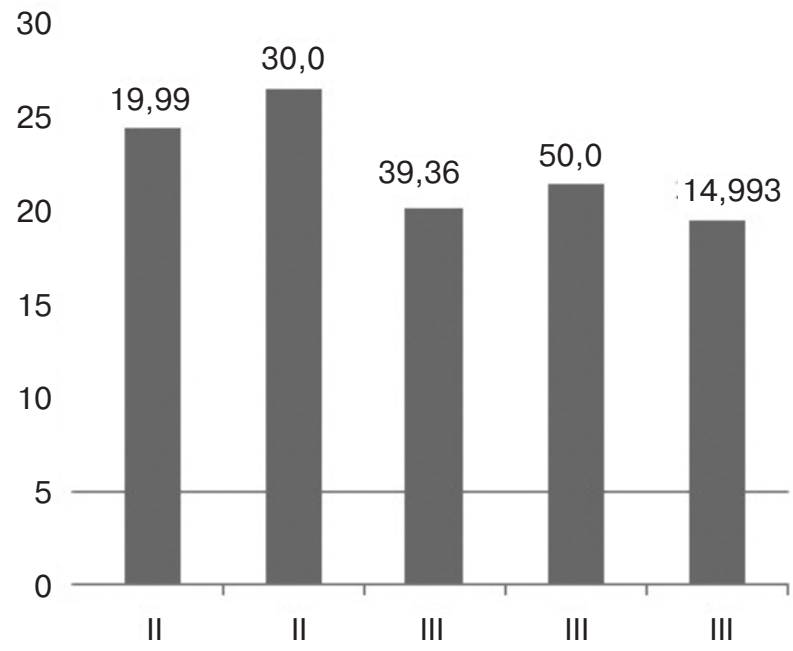

\section{Очікуване забруднення атмосферного повітря} специфічними забруднюючими речовинами (у частках ГДК) від АБЗ № 2 і № 3 з облаштуванням двоступеневою пило-газоочисною системою

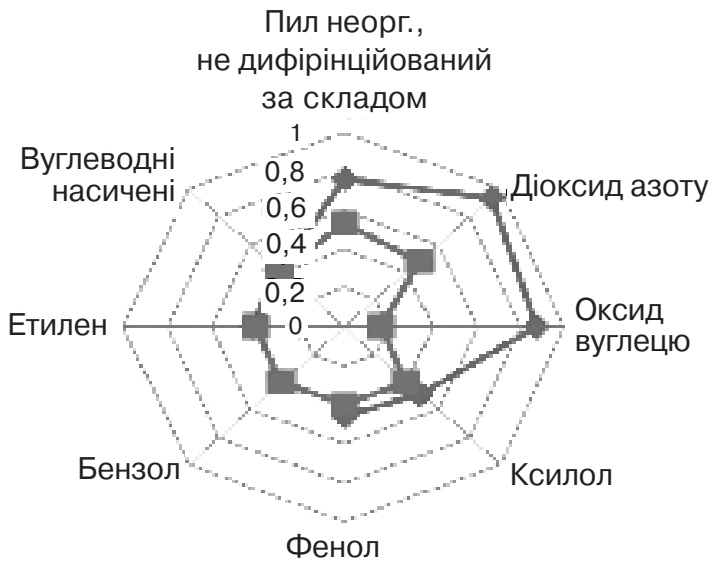

дії $з$ ефективністю роботи $78,9 \%)$ - на АБЗ № 1, № 4 та № 5; двоступенева система пило-газоочистки (циклон прямоточний та група з шести циклонів СЦН-40, скрубер «Вентурі» 3 коефіцієнтом очистки до 99,9\%) - на АБЗ № 2 та № 3 .

Ефективність роботи пилогазоочисних систем наочно показано на рисунку 1.

Аналіз розрахункових приземних концентрацій забруднюючих речовин в атмосферному повітрі від викидів АБЗ та з урахуванням фону показав, що їхні концентрації на межі запропонованих розмірів С33 не перевищували встановлених Гігієнічних регламентів допустимого вмісту хімічних і біологічних речовин в атмосферному повітрі населених місць, затверджених наказом MO3 № 52 від 14.01.2020, який зареєстровано у Мін'юсті 10.02.2020 за № 156/34439, та відповідали вимогам ДСП № 173-96 (п. 5.4).

Слід зазначити, що впровадження більш ефективних (триступеневих) систем пило-газоочистки значною мірою знижує концентрації специфічних забруднюючих речовин від джерел викидів АБЗ, що відповідає Директиві 2010/75/€C.

За чинною в Україні процедурою встановлення нових розмірів санітарно-захисних зон та на підставі поглибленого вивчення проектних матеріалів зазначених об'єктів було запропоновано до встановлення СЗ3 складної конфігурації за сторонами світу з такими розмірами: для АБЗ Філії «Кремінський райавтодор» - 920 м у південнозахідному та 910 м у західному напрямках; АБЗ Філії «Старобільська ДЕД» - 700 м у західному та 650 м у південнозахідному напрямках; АБЗ ТОВ «МЕГО ЛТД» - 480 м У південно-західному, 480 м у південному, 890 м у південносхідному напрямках; АБЗ ПрАТ «Ковельське ШБУ-63» 844 м у північно-східному, 785 м у східному, 724 м у південно-західному, 567 м у західному напрямках; АБЗ ТОВ «ДОРБУД» - 300 м у пів- 
нічно-західному, 315 м у західному, 392 м південнозахідному, 483 м у північному, 575 м у північно-східному напрямках 3 дотриманням нормативних розмірів у 1000 метрів в усіх інших напрямках від основних джерел викидів до найближчої житлової забудови, яка склалася у сучасних містобудівних умовах. Слід зазначити, що встановлення цих нормативів базувалося на положеннях вимог п. 5.4 ДСП 173-96, за якими СЗ3 встановлюється від джерел шкідливості до межі житлової забудови, ділянок громадських установ, територій парків, скверів.

Враховуючи використання новітніх технологій виготовлення асфальтобетонних сумішей, впровадження комплексу природоохоронних заходів, спрямованих на мінімізацію впливу викидів забруднюючих речовин від діяльності підприємств на навколишнє середовище, що досягається за рахунок використання сучасного технологічного обладнання, дотримання технологічного регламенту, герметизації технологічного обладнання та трубопроводів, автоматизації та механізації технологічного процесу, використання сучасного опалювального технологічного обладнання, очищення пило-повітряної суміші за допомогою дво- та триступеневої пило-газоочисної систем з ефективністю очистки до 99\%, забезпечення постійного контролю над роботою технологічного, очисного та опалювального обладнання, озеленення ССЗ, пропонується до розгляду та впровадження новий підхід до встановлення розмірів СЗ3 для АБЗ малої потужності - за розрахунковим методом, а саме: за розрахунками безпосередньо від організованих джерел (труб) забруднення атмосфери.

Запропонований новий гігієнічний підхід до встановлення СЗ3 за розрахунковим методом під час будівництва нових чи реконструкції існуючих АБЗ малої потужності відповідає вимогам новітнього
Закону України «Про внесення змін до Закону України «Про будівельні норми» щодо удосконалення нормування у будівництві» від 03.10.2019 р № 156-IX, за яким у будівництві об'єктів впроваджуються нові методи - параметричний та цільовий (пооб'єктний).

За результатами вивчення зарубіжного досвіду щодо унормування розмірів СЗ3 для виробництва асфальтобетону можна констатувати, що у нормативних документах європейських країн («Санитарно-защитные зоны и санитарная классификация организаций, сооружений и иных объектов. СанПиН МЗ и С3 ПМР 2.2.1/2.1.1.1200-07», Республіка Молдова) та країн пострадянського простору («Санитарно-защитные зоны и санитарная классификация предприятий, сооружений и иных объектов. СанПин 2.2.1/2.1.1.1200-03», РФ, «Требования к санитарно-защитным зонам организаций, сооружений и иных объектов, оказывающих воздействие на здоровье человека и окружающую среду. СанПин № 91 от 11.10.2017», Беларусь) нормативна С33 для зазначених об'єктів становить 500 м (що удвічі менше за нормативну СЗЗ в Україні) та не порушує вимог Директиви 2010/75/ЄС Європейського Парламенту та Ради з промислових викидів від 24.11.2010

\section{Очікуване забруднення атмосферного повітря специфічними забруднюючими речовинами (у частках ГДК) від АБЗ № 1, № 4, № 5 з облаштуванням триступеневою пило-газоочисною системою \\ Рисунок 3}

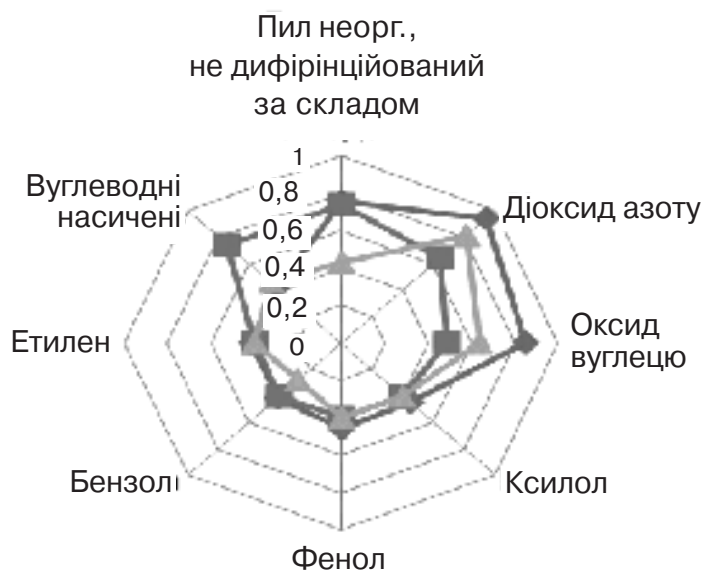

щодо впровадження найкращих доступних технологій.

У нормативних документах Польщі (D.04.07.01. Podbudowa z betonu asfaltowego) [6] значна увага приділяється якості асфальтобетону. При цьому розміщення підприємств відповідає санітарним розривам, які були визначені «Санитарными нормами проектирования промышленных предприятий. СН 245-71».

У зв'язку з тим, що нині вітчизняні підприємства з виробництва асфальтобетонних сумішей впроваджують сучасні технології з герметизацією виробничих процесів, високоефективні природоохоронні заходи, працюють на привізній сировині (готовому бітумі), необхідне впровадження нового гігієнічного підходу до встановлення нормативних розмірів СЗ3 у кожному конкретному випадку для АБЗ малої потужності за розрахунками безпосередньо від організованих джерел викидів .

\section{Висновки}

На підставі еколого-гігієнічної оцінки впливу діяльності підприємств з виготовлення асфальтобетону малої потужності на стан довкілля та санітарно-гігієнічні умови мешканців прилеглої житлової забудови можна констатувати:

1. Усі досліджені підприємства працюють на готовому бітумі з впровадженням природоохоронних заходів шля- 
хом використання високоефективних пило-газоочисних систем, що значною мірою скоротило валові викиди забруднюючих речовин в атмосферне повітря та зменшило вплив на довкілля і прилеглу сельбищну територію, що відповідає вимогам Директиви 2010/75/€С Європейського Парламенту та Ради з промислових викидів (інтегроване запобігання та контроль забруднення) від 24 листопада 2010 року.

2. Впровадження природоохоронних заходів з використанням високоефективних пило-газоочисних систем на існуючих АБЗ малої потужності забезпечило відсутність перевищень ГДК специфічних забруднюючих речовин на відстанях, які були меншими за нормативну С33 в 1,5-3,0 рази, що дає підстави для використання нового гігієнічного підходу до встановлення С33 - за пооб'єктнорозрахунковим методом.

ЛІТЕРАТУРА

1. Концепція Державної цільової економічної програми розвитку автомобільних доріг загального користування державного значення на 2018-2022 роки :

Розпорядження Кабінету Міністрів від 11.01.2018. URL : http://zakon.rada.gov.ua/ go/34-2018-p

2. Makhniuk V.M.,

Harkavyi S.I., Styrta Z.V., Harkavyi S.S. Ecohygienic assessment of the effect of enterprises activity producing asphalt concrete on the condition of environment taking into account the requirement of local legislation and EU directive. Довкілля та здоров'я. 2019. № 2 (91). С. 41-46.

3. Сердюк А.М., Полька Н.С., Махнюк В.М. та ін. Гігієна планування та забудови населених місць на варті громадського здоров'я (до 85-річного ювілею ДУ «нсститут громадського здоров'я ім. О.М. Марзєєва НАМН України»). К. Медінформ, 2017. 271 с.

4. Про промислові викиди (інтегроване запобігання та контроль забруднення) :
Директиви 2010/75/ЄС

Європейського Парламенту та Ради від 24.11.2010. URL https://www. kmu.gov.ua/storage/app/sites/1/55GOEEI/\%202010

$75 \% D 0 \% 84 \%$ DŌ\%A1.pdf

5. Линник I.E. Оцінка та прогнозування екологічного стану дорожнього господарства. Харків : Харківський національний університет міського господарства ім. О.М. Бекетова, 2017. $143 \mathrm{c}$.

6. D.04.07.01. Podbudowa z betonu asfaltowego. URL : http://szpital.kalisz.pl/ stronka/SIWZ/04_Podbudowa_beto nu_asfaltowego.pdf

7. Kondratenko O. Onysko I. Development of environmental protection technology from the negative impact of the production activity of the asphalt concrete production factory.

Development of Modern

Science under Global Changes : International Scientific

Conference. Riga, Latvia :

Baltija Publishing, 2020.

P. 80-84. URL :

https://doi.org/10.30525/9789934-588-52-5-26

\section{REFERENCES}

1. Kontseptsiia Derzhavnoi tsilovoi ekonomichnoi prohramy rozvytku avtomobilnykh dorih zahalnoho korystuvannia derzhavnoho znachennia na 2018-2022 roky :

Rozporiadzhennia Kabinetu Ministriv vid 11.01.2018. [The Concept of the State Target Economic Program for the Development of the Highway of State Importance for 20182022: Order of the Cabinet of Ministers, 11.01.2018]. URL : http://zakon.rada.gov.ua/go/3 4-2018-p

(in Ukrainian).

2. Makhniuk V.M., Harkavyi S.I., Styrta Z.V. and Harkavyi S.S. Ecohygienic Assessment of the Effect of Enterprises Activity Producing Asphalt Concrete on the Condition of Environment

Taking into Account the Requirement of Local Legislation and EU Directive. Dovkillia ta zdorovia (Environment \& Health). 2019 ; 2 (91): 41-46.
3. Serdiuk A.M., Polka N.S., Makhniuk V.M. et al.

Hihiiena planuvannia ta zabudovy naselenykh mists na varti hromadskoho zdorovia (do 85-richnoho yuvileiu DU «Instytut hromadskoho zdorovia im. O.M. Marzieieva NAMNU») [Hygiene of Planning and Construction of the Settlements on the Watch of Public Health (in commemoration of the 85-th Anniversary of SI «Marzieiev Institute for Public Health, NAMSU»)]. Kyiv : Medinform ; 2017 : 271 (in Ukrainian).

4. Pro promyslovi vykydy (intehrovane zapobihannia ta kontrol zabrudnennia) : Dyrektyvy 2010/75/YeS Yevropeiskoho Parlamentu ta Rady vid 24 lystopada 2010 roku [On the Industrial Emissions (Integrated Pollution Prevention and Control): Directive 2010/75 / EC of the European Parliament and Council, 24 November, 2010]. URL:

https://www.kmu.gov.ua/storage/app/sites/1/55-GOEEI/\% 202010 75 \% D0\% 84\% D0\% A1.pdf (in Uk̄rainian).

5. Lynnyk I.E. Otsinka ta prohnozuvannia ekolohichnoho stanu dorozhnoho hospodarstva [Assessment and Prediction of the Ecological State of Road Industry]. Kharkiv : Kharkiv National University of Municipal Economy ; 2017 : 143 (in Ukrainian).

6. D.04.07.01. Podbudowa z betonu asfaltowego. Access mode :

http://szpital. kalisz.pl/ stronka/SIWZ/04 Podbudowa beto nu_asfaltowēgo.pdf (in Pölish).

7. Kondratenko $\mathrm{O}$. and Onysko I. Development of Environmental Protection Technology from the Negative Impact of the Production Activity of the Asphalt Concrete Production Factory. In :

Development of Modern

Science under Global Changes : International Scientific

Conference. Riga, Latvia :

Baltija Publishing; 2020 : 80-

84. URL : https://doi.org/ 10.30525/978-9934-588-525-26.

Надійшло до редакції 17.08.2020 